\title{
Available water influences field germination and recruit- ment of seeded grasses
}

\author{
LAURIE B. ABBOTT AND BRUCE A. ROUNDY
}

Authors are Assistant Professor, Department of Animal and Range Sciences, New Mexico State University, Las Cruces, N.M., 88003; and Professor, Department of Integrative Biology, Brigham Young University, Provo, Utah, 84602.

\begin{abstract}
Periodic summer rainstorms in some semi-arid regions result in variable soil moisture and differential establishment of seeded species. A 2-year study investigated soil water effects on germination and survival of 6 native and 2 non-native southwestern U.S. grass species. Bags of seeds were buried and retrieved before and during the summer rainy season. High field germination in seed bags $(20-100 \%)$ and limited germination in the laboratory of seeds that were ungerminated in seedbags $(0-45 \%)$ were exhibited by 6 native grasses following initial rainfall events in which the surface soil was saturated for 2 days or water potential (1-3 cm depth) was above $-1.5 \mathrm{MPa}$ for more than 9 days. Fewer Lehmann lovegrass (Eragrostis lehmanniana Nees) seeds germinated in response to initial and subsequent rainfall events $(0-49 \%)$, but this species retained more residual germinable seeds (49-99\%) than all other species studied. For 2 sowing dates, the soil drying front exceeded estimated seminal root depth 13 days after germination. Lack of recruitment for some species sown on these dates was probably due to seedling desiccation before adventitious roots had sufficient time to develop. The ability of Lehmann lovegrass to retain a viable seedbank when rainstorms are separated by long dry periods allows it to establish better than some native grasses that germinate quickly and are then subject to seedling desiccation. During a summer with more consistent rainfall, native species recruitment was greatest when seeds were planted during, rather than before the summer rainy season.
\end{abstract}

Key Words: warm-season, desert grassland, rangeland revegetation, drought tolerance, Bouteloua curtipendula, Bothriochloa barbinodis, Leptochloa dubia, Digitaria californica, Muhlenbergia porteri, Eragrostis lehmanniana, Eragrostis intermedia, Eragrostis lehmanniana X tricophera

In semi-desert grasslands of the southwestern United States, native warm-season perennial grass seedings often fail while those of perennial non-native species are successful (Cox et al. 1982, Roundy and Biedenbender 1995). Lehmann lovegrass (Eragrostis lehmanniana Nees), a warm-season perennial bunchgrass introduced from South Africa, is commonly used for revegetation because of its reliable establishment (Cox et al. 1982).

Summer precipitation in the southwestern United States is spo-

Research was funded in part by the Arizona Agricultural Experiment Station, the U.S. Department of Agriculture Rangeland Competitive Grant Program, and Brigham Young University Professional Development Funds. The authors thank Sharon Biedenbender and Kevin Williams for assistance in the field. We also thank Guy R. McPherson and Steven E. Smith for insightful discussions, statistical advice, and their review of an earlier draft of the manuscript.

Manuscript accepted17 Apr. 02.

\section{Resumen}

Las tormentas periódicas de verano que ocurren en algunas regiones semi-áridas resultan en una humedad del suelo variable y un establecimiento diferencial de las especies sembradas. Un estudio de 2 años investigó los efectos del agua del suelo en la germinación y sobreviviencia de 6 especies de pastos nativos del sudoeste de Estados Unidos y 2 introducidas. Bolsas con semilla se enterraron y recuperaron antes y durante la estación de lluvias de verano. La alta germinación en campo en las bolsas de semilla (20-100\%) y la germinación limitada en el laboratorio de las semillas que no germinaron en las bolsas $(0-45 \%)$ se presentó en las 6 especies de zacates nativos después de los eventos iniciales de lluvia en los cuales la superficie del suelo se saturó por 2 días o el potencial del agua (1-3 cm de profundidad ) estuvo arriba de -1.5 MPa por mas de 9 días. Pocas semillas de "Lehmann lovegrass" (Eragrostis lehmanniana Nees) germinaron en respuesta de los eventos de lluvia iniciales y subsecuentes (0-49\%), pero esta especie retuvo mas semillas germinables residuales $(49-99 \%)$ que cualquier otra de las especies estudiadas. En dos fechas de siembra el frente de secado del suelo excedió la profundidad estimada de las raíces seminales a los13 días después de la germinación. La falta de establecimiento de algunas especies sembradas en estas fechas probablemente se debido a la desecación de la plántula antes de que las raíces adventicias tuvieran suficiente tiempo para desarrollarse. La habilidad del "Lehmann lovegrass" para mantener un banco de semilla viable cuando las tormentas son separadas por periodos secos largos le permite establecerse mejor que algunos zacates nativos que germinan rápidamente y entonces están sujetos a la desecación de la plántula. Durante un verano con lluvia mas consistente, el establecimiento de especies nativas fue mayor cuando las semillas se sembraron durante, en lugar de antes, la estación lluviosa de verano.

radic (Humphrey 1958, McClaran 1995), resulting in variable soil water availability during the growing season. Where soil water drying is rapid, strategies to avoid, rather than tolerate drought, may be most useful. The fate of seeds and seedlings is the result of 1) whether or not seeds germinate during a wet period, and 2) the length of water availability during the subsequent dry period (Frasier and Lopez 1990). If wet periods are short and infrequent, fast-germinating species are likely to fail because their seminal roots will not stay ahead of the soil drying front long enough for adventitious roots to develop and supply water to the seedling. One to several weeks of soil water availability at the location of 
the coleoptilar node near the soil surface is generally required for warm-season grass seedlings to develop adventitious roots (Wilson and Briske 1979, Ries and Svejcar 1991, Roundy et al. 1993, Abbott 1999). Depending on ambient conditions, short, infrequent rainstorms may not even wet the seedling root zone for longer than a few days (Roundy et al. 1997). Slower-germinating species may not germinate but remain germinable during short wet periods. This may increase their probability of establishment by delaying germination until sufficient rain has fallen to ensure longer water availability to roots. Slower germination may favor recruitment, if initial summer rainfall is less consistent than later summer rains. Although rainfall patterns are highly variable from year to year, long-term records from southeastern Arizona indicate that storms are generally less frequent in the beginning of the summer rainy season than later in the season (Smith and Schreiber 1973, Frasier and Lopez 1990, Roundy et al. 1996).

In southeastern Arizona, the recommended time to reseed warm-season grasses has been in May or June, prior to the beginning of the summer rainy season (Jordan 1981). Utilizing these seeding practices, successful rangeland reseedings in this region can be expected in 1 of 10 years (Cox and Jordan 1983). In greenhouse studies in sandy soil, Frasier et al. (1984, 1985) and Frasier (1989) found that slower-germinating warm-season grasses were more likely to establish than fastergerminating native grasses when initial short wet periods and subsequent long dry periods were followed by long wet periods.

These results led us to predict that recruitment of fast-germinating native grasses could be improved by seeding them during, rather than before the onset of summer rains. We tested the effects of sowing date on field germination, residual germination (percentage of seeds not germinating in the field but still able to germinate), and seedling recruitment.

\section{Materials and Methods}

\section{Study Site}

Studies were conducted in a semi-desert grassland site at the Santa Rita Experimental Range, approximately 40 $\mathrm{km}$ southwest of Tucson, Ariz. $\left(31^{\circ} 47^{\prime} \mathrm{N}\right.$. lat., $110^{\circ} 37 \mathrm{~W}$. long.). The site is located on an alluvial fan with a maximum slope of $5 \%$; elevation is $1,075 \mathrm{~m}$ (Cox et al. 1990). Annual precipitation averaged 415 $\mathrm{mm}$ over the last 30 years, and varied between 205 and $765 \mathrm{~mm}$ (SRER 1999). Precipitation is bimodally distributed, with approximately $60 \%$ falling as rain between July and September, and most of the remaining $40 \%$ falling as rain or snow between October and April (Cox et al. 1990, Roundy et al. 1997). Air temperatures range annually between $0^{\circ}$ and $40^{\circ} \mathrm{C}$ (Green and Martin 1967).

Soils are classified as coarse-loamy, mixed, superactive, nonacid, thermic Typic Ustic Torrifluvents and coarseloamy, mixed, superactive, thermic Ustic Haplargids of the Combate-Diaspar complex, and the site is classified as a complex of sandy loam upland and deep sandy loam range sites in the 305 to $406 \mathrm{~mm}$ precipitation zone (Breckenfeld and Robinett 1997). Research was conducted within a livestock exclosure that had been fenced since 1984. The area inside the exclosure supports a herbaceous community dominated by Lehmann lovegrass. Nearby vegetation is typical semi-desert grassland with an overstory of velvet mesquite (Prosopis velutina Woot.) and a shrubby understory of burroweed (Happlopappus tenuisectus [Green] Blake), catclaw aca- cia (Acacia greggii Gray), false mesquite (Calliandra eriophylla Benth.), and prickly pear Opuntia Miller spp. Common native perennial grasses include threeawns (Aristida L. spp.), Arizona cottontop (Digitaria californica [Benth.] Chase), sideoats grama (Bouteloua curtipendula [Michx.] Torr.), Rothrock grama ( $B$. rothrockii Vasey), black grama (B. eriopoda Torr.), slender grama (B. filiformis [Fourn.] Griffiths), and sprucetop grama (B. chondrosioides [H.B.K.] Benth.) (Martin 1966). Experimental plots were mowed, raked, and sprayed with glyphosate ( $\mathrm{N}$-[phosphonomethyl] glycine, a non-selective herbicide) and were maintained relatively free of non-study vegetation by mowing, hoeing, and raking.

Two field studies were conducted concurrently during the summers of 1992 and 1993 using 8 warm-season perennial grass species (Table 1). Prior to sowing all seeds were mechanically cleaned to remove appendages from caryopses. Seeds were sown before summer rains on 16 June 1992 and 15 June 1993, and after summer rains began on 30 July 1992 and 2 August 1993. Experiments were replicated in 3 blocks.

\section{Germination Study}

This experiment employed a randomized complete block design in a split-splitsplit-plot factorial arrangement, with year as the main factor, sowing date as level 2 , species as level 3 , and retrieval date as level 4. Seeds were retrieved twice after each sowing to determine changes in germination over time. The first retrieval occurred as the top $1 \mathrm{~cm}$ of soil was drying after the initial rainfall event. The second retrieval followed after at least 1 subsequent rainfall and drying event.

Seeds were placed in nylon mesh bags prior to burial to facilitate recovery of all

Table 1. Common and scientific names of species used in germination and recruitment studies.

\begin{tabular}{|c|c|c|c|}
\hline \multicolumn{2}{|c|}{ Scientific Name } & \multirow[t]{2}{*}{ Common Name } & \multirow[t]{2}{*}{ Seed Source } \\
\hline Native: & & & \\
\hline & Bouteloua curtipendula (Michx.) Torr. & Sideoats grama & Native Plants, Inc., Arizona \\
\hline & Leptochloa dubia (H.B.K.) Nees & Green sprangletop & Granite Seed Co.,Utah; Texas origin \\
\hline & Bothriochloa barbinodis (Lag.) Herter & Cane beardgrass & $\begin{array}{l}\text { Tucson Plant Materials Center, Arizona, } \\
\text { Natural Resource Conservation Service }\end{array}$ \\
\hline & Digitaria californica (Benth.) Chase & Arizona cottontop & Granite Seed Co.,Utah; Arizona origin \\
\hline & Muhlenbergia porteri Scribn. & Bush muhly & Collected Jornada Expt. Range, New Mexico \\
\hline & Eragrostis intermedia Hitchc. & Plains lovegrass & Native Plants, Inc., Arizona \\
\hline \multicolumn{4}{|c|}{ Non-native: } \\
\hline & Eragrostis lehmanniana Nees & Lehmann lovegrass & Native Plants, Inc., Arizona \\
\hline & Eragrostis lehmanniana Nees $\mathrm{x}$ & Cochise lovegrass & Native Plants, Inc., Arizona \\
\hline & E. trichophora Coss and Dur. & & \\
\hline
\end{tabular}


planted seeds. Individual bags contained 10 pure live seeds of 1 species and were buried at 3-5 mm depth; bags contained seeds only, and did not contain soil. Sample sizes differed in the 2 years. Six bags of each species were buried in each block on each sowing date in $1992(\mathrm{~N}=$ 18), resulting in a sample size of 9 bags per sowing date/species/retrieval date. In 1993, 4 bags of each species were buried on each sowing date in each of three blocks $(\mathrm{N}=12)$, resulting in 6 bags per sowing date/species/retrieval date.

Seeds in retrieved bags were inspected for germination; a seed was considered germinated if the radicle visibly protruded beyond the testa. Ungerminated seeds were placed on wetted filter paper in petri dishes and placed in a $25^{\circ} \mathrm{C}$ constant-temperature germination chamber. Seeds were checked daily for germination, and those that germinated in the germination chamber were considered germinable. Seeds that did not germinate after 14 days in the germination chamber were considered dead or dormant. Due to difficulties in differentiating between dead and dormant seeds following this procedure, dead or dormant seeds were excluded from analysis and interpretation; subsequent analyses were conducted on the proportion of seeds that had germinated in the field or were germinable after retrieval.

\section{Recruitment Study}

This experiment employed a randomized complete block design in a split-splitplot factorial arrangement, in which year was the main factor, sowing date was level 2 , and species was level 3 . Within each sowing date/species treatment combination there were 10 circular sub-plots (cylinders), each of which was $15 \mathrm{~cm}$ in diameter. Cylinders were constructed by excavating $15 \times 15 \mathrm{~cm}$ pits to a depth of approximately $5 \mathrm{~cm}$, placing a $15-\mathrm{cm}$ diameter by $7.5-\mathrm{cm}$ deep cylinder of PVC pipe into the pit, and backfilling around the outside of the cylinder. Each cylinder was then filled with sandy loam soil. Precautions were taken to reduce the potential of contamination of the cylinders with seeds of the extant seedbank. In 1992, cylinders were filled with autoclaved soil collected from the study site. In 1993, off-site soil was imported from an undisturbed location where the soil profile supported a deep layer of sandy loam very similar to the soil at the study site; the surface $10 \mathrm{~cm}$ of soil was not used in the study. On each sowing date, 25 pure live seeds of a single species were planted into each cylinder. Consistent with typical recommendations for the species (Jordan 1981), small-seeded species (lovegrasses) were covered with approximately $0.5 \mathrm{~cm}$ of soil, and larger-seeded species were covered with approximately $1 \mathrm{~cm}$ of soil. The number of surviving seedlings in each cylinder was recorded at the end of each season. Recruitment was calculated as a percentage of seeds sown.

\section{Environmental Data}

Throughout the observation period, soil moisture and temperature were recorded in each block, as described by Roundy et al. (1997). Soil moisture was estimated with calibrated Colman fiberglass soil cells (Colman and Hendrix 1949) at 5 depths in the soil: 1-3, 4-6, 8-10, 12-14, and 18-20 $\mathrm{cm}$. Temperature was measured with copper-constantan thermocouples buried at 1 , $2,5,9,13$, and $19 \mathrm{~cm}$. At each depth, soil moisture measurements were replicated with 5 soil cells in each of 3 blocks, and temperature measurements were replicated using 3 thermocouples. Ambient climatic data (precipitation, air temperature, relative humidity, wind speed, and incident solar radiation) were measured on site. Measurements were recorded every minute using dataloggers (CR-10, Campbell Scientific Inc., Logan, Utah) and stored as an hourly sum for precipitation and as hourly means for all other variables.

\section{Data Analysis}

Germination response and seedling establishment data were analyzed using likelihood-based methods appropriate for general linear mixed models (MIXED procedure in SAS; Littel et al. 1996). Blocks were considered random effects, whereas all other factors (year, sowing date, species, and retrieval date) were considered fixed effects. The data were not normally distributed, and consequently were rank-transformed prior to analysis (Conover and Iman 1981). Nylon bags served as replicates in the germination response study; cylinders served as the replicates in the seedling establishment study.

\section{Results and Discussion}

\section{Rainfall and Soil Moisture Patterns}

Total precipitation and distribution of precipitation during the summer months differed between 1992 (Fig.1a) and 1993 (Fig. 1b). Total rainfall between 1 July and 10 September was greater in 1992 (219 $\mathrm{mm})$ than $1993(157 \mathrm{~mm})$, but rainfall was more frequent in 1993 than 1992. Therefore, available water in the surface soil (matric potential $>-1.5 \mathrm{MPa}$ at $1-3$ $\mathrm{cm})$ was 2.3 days greater in 1993 (39.7 days) than in 1992 (37.4 days) for this same period. Seeds for each sowing date and retrieval were exposed to different ini-

Table 2. Wet (soil matric potential at 1-3 cm deep >-1.5 MPa) and dry periods associated with 8 seed bag retrieval dates for warm-season grasses in southeastern Arizona.

\begin{tabular}{|c|c|c|c|c|c|c|c|c|c|c|c|c|c|c|}
\hline \multirow{2}{*}{$\begin{array}{l}\text { Available } \\
\text { Water } \\
\text { Period }\end{array}$} & \multirow{2}{*}{$\begin{array}{l}\text { Date } \\
\text { Sown }\end{array}$} & \multirow{2}{*}{$\begin{array}{c}\text { Date } \\
\text { Retrieved }\end{array}$} & \multicolumn{3}{|c|}{$\begin{array}{l}\text { Total time of seed bag } \\
\text { burial beginning with } \\
\text { first wet period }\end{array}$} & \multirow{2}{*}{$\begin{array}{l}\text { Total } \\
\text { Time } \\
\text { Wet }\end{array}$} & \multirow{2}{*}{$\begin{array}{l}\text { Initial } \\
\text { Wet } \\
\text { Period }\end{array}$} & \multicolumn{6}{|c|}{ Chronological wet-dry times } & \multirow[b]{2}{*}{ Dry } \\
\hline & & & Wet & Dry & Total & & & Dry & \multirow[t]{2}{*}{ Wet } & Dry & \multirow{2}{*}{$\frac{\text { Wet }}{\text { vs) - - }}$} & Dry & Wet & \\
\hline & & & $-\cdots$ & Days & $\ldots \ldots$ & $(\%)$ & & & & $\cdots$ & & - & -- & \\
\hline S 1 & 16 Jun 1992 & 10 Jul 1992 & 2.3 & 0.0 & 2.3 & 100 & 2.3 & & & & & & & \\
\hline L 2 & 16 Jun 1992 & $20 \mathrm{Jul} 1992$ & 9.3 & 3.0 & 12.3 & 76 & 9.3 & 3.0 & & & & & & \\
\hline L 3 & $30 \mathrm{Jul} 1992$ & 12 Aug 1992 & 11.1 & 1.9 & 13.0 & 85 & 11.1 & 1.9 & & & & & & \\
\hline L 4 & $30 \mathrm{Jul} 1992$ & 9 Sep 1992 & 20.3 & 20.8 & 41.1 & 49 & 11.1 & 7.2 & 0.8 & 4.7 & 8.3 & 8.9 & & \\
\hline S 5 & 15 Jun 1993 & 5 Jul 1993 & 2.8 & 1.0 & 3.8 & 74 & 2.8 & 1.0 & & & & & & \\
\hline S 6 & 15 Jun 1993 & 20 Jul 1993 & 11.1 & 7.1 & 18.2 & 61 & 2.8 & 4.4 & 1.6 & 0.1 & 2.8 & 0.3 & 3.9 & 2.3 \\
\hline L 7 & 2 Aug 1993 & 16 Aug 1993 & 12.7 & 1.3 & 14.0 & 91 & 12.0 & 1.3 & 0.7 & & & & & \\
\hline L 8 & 2 Aug 1993 & 28 Aug 1993 & 22.6 & 3.4 & 26.0 & 87 & 12.0 & 1.3 & 5.8 & 2.1 & 4.8 & & & \\
\hline
\end{tabular}



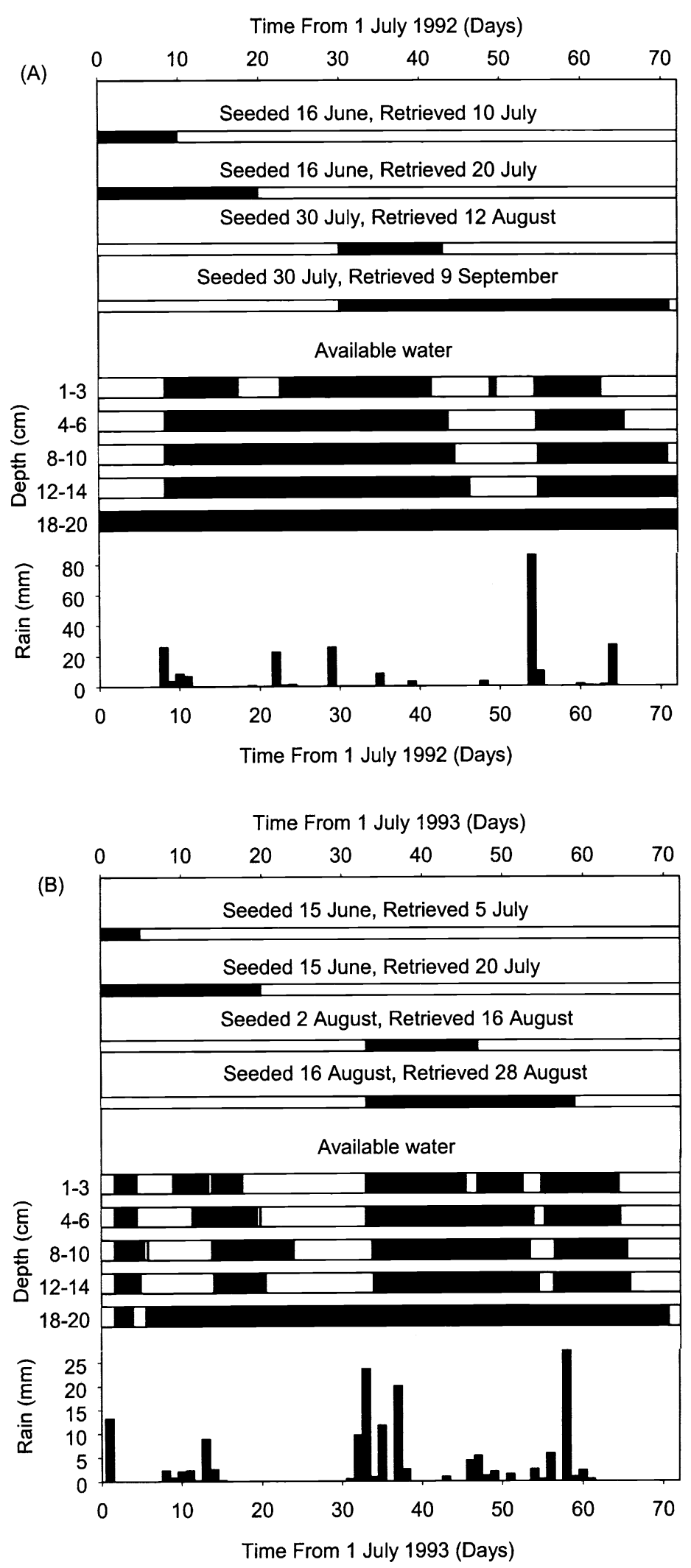

Fig. 1. Daily precipitation (vertical bars), time of seed exposure to soil, and soil moisture availability patterns when volumetric soil water content $>$ a matric potential equivalent of $-1.5 \mathrm{MPa}$ (dark horizontal bars indicate periods of available soil moisture) at the Santa Rita Experimental Station field site for the summers of 1992 (A) and 1993 (B). tial and subsequent available water periods (Table 2). Out of the 8 different retrievals ( 2 years $\times 2$ sowing dates $\times 2$ retrievals), seeds in 3 retrievals had short initial available water periods of 2.3-2.8 days ( $\mathrm{S} 1, \mathrm{~S} 5$, S6-Table 2), while seeds in 5 retrievals were exposed to much longer initial wet periods of 9.3-12 days (L2, L3, L4, L7, L8-Table 2). Subsequent to the initial wet period, seeds in the different retrievals were exposed to a range of dry periods lasting from 0 to 7.2 days. Total exposure to available water while seeds were buried ranged from 2.3 to 22.6 days across the 8 retrievals. Percentage of burial time that seeds were exposed to available water beginning with initial wetting ranged from $49-100 \%$. For the 2 years of this study, seeds sown in the middle of the rainy season (30 July 1992 and 2 August 1993) were exposed to longer initial periods of available water (11.1 and 12 days) than those sown prior to the rainy season (16 June 1992-2.3 days and 15 June 1993-2.8 days). Greater precipitation in 1992 than 1993 resulted in more continuous periods of available water at soil depths of 4-14 $\mathrm{cm}$ for 1992 than 1993, but water was continuously available at $18-20 \mathrm{~cm}$ from 8 July through 8 September in both years (Fig. 1).

\section{Germination Study}

For field germination, all main effects except year ( $\mathrm{df}=1,64$ for year and sowing date, $\mathrm{df}=7,64$ for species), and all 2 and 3 - way interactions of year, sowing date, species, and retrieval $(\mathrm{df}=7,64)$ were significant $(\mathrm{P}<0.05)$ except for species $\mathrm{x}$ sowing date. The significance level of the 4- way interaction of year $x$ sowing date $x$ species $\mathrm{x}$ retrieval date for field germination was $\mathrm{p}=0.079(\mathrm{df}=7,64)$. For residual germination, all main effects $(\mathrm{df}=$ 1,64 for year and sowing date, $\mathrm{df}=7,64$ for species) and 2, 3, and 4-way interactions $(\mathrm{df}=7,64)$ were significant $(\mathrm{P}<$ 0.05 ) except for the interaction of year $x$ species $x$ retrieval. The significance of these interactions suggests that field and residual germination responses might best be understood in terms of the response of each species to the 8 different available water periods experienced. Therefore, for each species, 28 pair-wise t- tests were conducted for field and residual germination among these 8 periods using a significance level of $\mathrm{P}<0.05 / 28$ (Fig. 2)

\section{Short initial available water periods}

For 2 of the 3 retrievals that had initially short available water periods ( $\mathrm{S} 1, \mathrm{~S} 6)$, most species had high to moderate field 

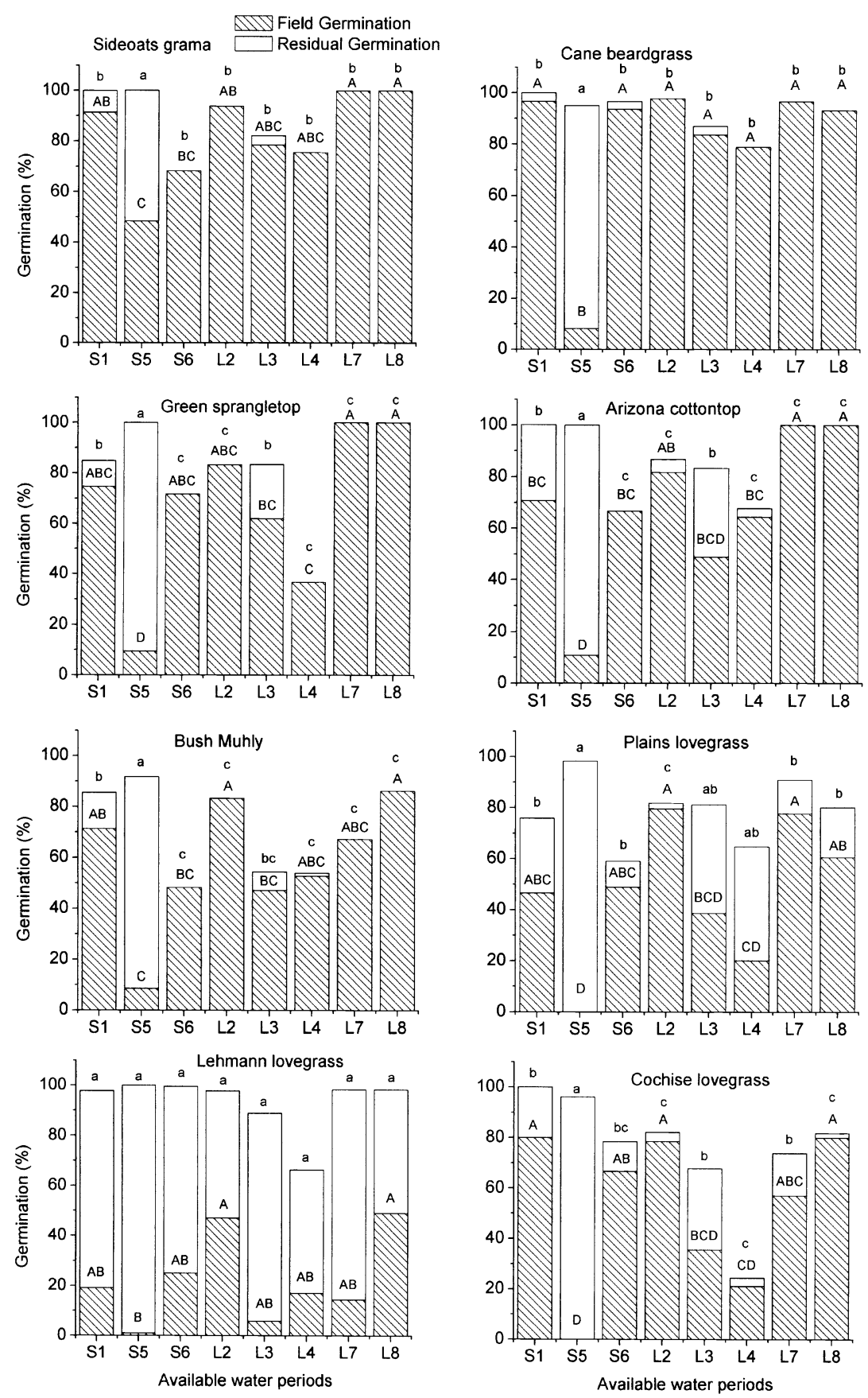

Fig. 2. Field (hatched bars) and residual (open bars) germination percentages of warm-season grasses sown on 4 dates and experiencing 8 different available water periods (Table 2). Means for different available water periods with the same letter are not significantly different $(p=0.05 / 28)$ for a species. Means separation for field germination indicated with uppercase letters; means separation for residual germination indicated with lowercase letters.

germination and moderate to limited residual germination (Fig. 2). In contrast, the retrieval that most differed in germination from all others was that associated with available water period S5, which produced limited to no field germination and high residual germination. Seeds for this retrieval experienced 2.8 days of available days prior to retrieval. In contrast, seeds from S5 received $13 \mathrm{~mm}$ rainfall and soil water content was near saturation for about 0.8 days, decreased to a matricpotential equivalent of $-1.5 \mathrm{MPa}$ over the next 2 days, and were dry for the last day prior to retrieval. Seeds retrieved after available water period S6 were exposed to 4 wet-dry periods before retrieval, with the first dry period being 4.4 days long (Table 2 ). Total germination for some species was less for this available water period than for S1 and S5, suggesting that some seeds germinated and died during the dry periods.

\section{Long initial available water periods}

Most species had moderate to high field germination and limited to moderate residual germination after initial exposure to long wet periods ( $>9$ days; L2, L3, L4, L7, L8- Table 2). For all species, field germination that was maximum or not significantly different from the maximum occurred for seeds sown 2 August 1993 and retrieved 14 or 26 days later (L7, L8, Table 2). These seeds experienced 12 days of available water immediately after sowing and had limited exposure to dry soil (< 2.1 days). Field germination was also maximum for seeds with available water period L2, consisting of 9.3 days of available water and 3 dry days. Total or field germination for some species was less for available water periods L3 and L4 than for L2, L7, and L8 (Fig. 2). For available water period $\mathrm{L} 4$, seeds were exposed to a 7.2- day dry period after initial exposure to 11.1 days wet. Some seeds may have died or gone dormant during that long dry period.

\section{Species responses}

The different species exhibited specific germination behavior in relation to the different available water periods (Fig. 2). Most obvious was the conservative germination behavior of Lehmann lovegrass compared to the other species. Lehmann lovegrass had less than $50 \%$ field germination and very high residual germination for all retrievals. Except for seeds associated with available water period S5, most other species had much higher field than residual germination. Sideoats grama, cane beardgrass (Bothriochloa barbinodis [Lag.] Herter), and bush muhly (Muhlenbergia porteri Scribn.) especially had very limited residual germination. Green sprangletop (Leptochloa dubia H.B.K.), Arizona cottontop, plains lovegrass (Eragrostis intermedia Hitch.), and Cochise lovegrass (Eragrostis lehmanni- 
ana Nees x E. trichophora Coss and Durr.) all had residual germination of $>20$ $\%$ for certain available water periods. Besides available water period S5, period L3 produced the highest residual germination in these species. Seeds for this retrieval were sown in wet soil 30 July 1992 and retrieved after 11.1 days of wet soil and 1.9 days of dry-soil exposure. These seeds sown in wet soil may not have imbibed as fast as those exposed to the saturating conditions of initial rain (L2, L7, L8) and may have had slower germination and therefore higher residual germination for this retrieval.

\section{Sowing dates}

Overall, field germination was about $10 \%$ lower and residual germination about $16 \%$ higher for seeds sown prior to, rather than in the middle of the rainy season. This could be attributed to the longer initial wet periods for the mid-season sowing dates (Table 2). Seeds from the second retrievals should be more indicative of potential field establishment than those from the first retrievals because they experienced a longer period of exposure to subsequent wet and dry periods. For the second retrievals, seeds sown prior to the rainy season in 1992 (L2) had greater field germination $(80.6 \%)$ than those sown in the middle of the rainy season (L4$45.8 \%$ ). The reverse was true for 1993 where seeds sown prior to the rainy season (S6) had $61.2 \%$ field germination and those sown in the middle of the season (L8) had $83.6 \%$. Germination responded more to actual available water patterns after sowing than to the date of sowing.

\section{Germination and hydrotime}

Seed requirements for a critical minimum level of hydration necessary for germination are species-specific and vary widely (Collis-George and Sands 1959 , Hegarty 1978). Gummerson (1986) and Bradford (1990) developed germination models that incorporate dynamic seed water potentials as would be encountered under field conditions of variable soil moisture availability. These models incorporate 2 components of hydration: base water potential (i.e., potentials below which fewer than $50 \%$ of seeds germinate), and hydrotime (i.e., accumulated time that seed water potential is above the base water potential). Using grass species common to the present study, Adams (1997) developed parameters for a hydrotime model conceptualized by Gummerson (1986) and Bradford (1990). He found that Lehmann lovegrass and sideoats grama are capable of initiating germination at relatively low water potentials, but Lehmann lovegrass required much longer exposure time than sideoats grama to complete germination. Whereas sideoats grama and Cochise lovegrass both required relatively short exposure to base water potentials to germinate, Cochise lovegrass required more available water (higher base water potential) than sideoats grama (Adams 1997).

Relative rates of germination under field conditions are in general agreement with previous studies of emergence. Maximum emergence of sideoats grama was reached in 2-3 days in greenhouse and growth chamber studies (Olmsted 1941, Frasier et al. 1984, 1985, Adams 1997); this pattern is expected for a species that has a short hydrotime requirement and the potential to germinate at a wide range of soil water potentials. Similarly, delayed emergence of Lehmann lovegrass has been observed in greenhouse and growth-chamber emergence studies (Frasier et al. 1985, 1987, Adams 1997), and is predicted for a species capable of germinating at a wide range of soil water potentials with a long hydrotime requirement.

Species-specific differences in hydration requirements are most clearly demonstrated by examination of the 15 June 1993 sowing; the first rainfall after sowing was scant and seeds were retrieved after approximately 2 days from a drying soil (matric potential at $1-3 \mathrm{~cm}$ above -1.5 $\mathrm{MPa})$. Germination for the first retrieval date of that sowing (S5) was relatively low (0-11\%) for all species except sideoats grama $(48 \%)$, yet by the second retrieval (S6), germination ranged from $48 \%$ to 94\% for all species except Lehmann lovegrass. In a growth chamber study, cane beardgrass, bush muhly, and Cochise lovegrass reached $50 \%$ germination in 1.7 days (Roundy and Biedenbender 1996); thus, field germination after the first retrieval was less than expected for these species.

Low germination in the present study would result if soil matric potentials at the depth of seeds were lower than the base water potentials for those species. It is likely that soil drying occurred more quickly at the $<1.0-\mathrm{cm}$ depth of seed burial than at the $1-3-\mathrm{cm}$ depth of the soil moisture sensors. Under drying soil conditions, species with high base water potentials probably did not have sufficient time to complete germination; sideoats grama germination could proceed as long as the soil matric potential did not drop below $1.68 \mathrm{MPa}$ (Adams 1997). Residual germinability following the first retrieval of the 15 June 1993 sowing was generally high $(>83 \%)$ for all species except sideoats grama. The second period of favorable moisture conditions lasted approximately 8.3 days with 2 intermittent dry periods of 0.1 and 0.3 days (S6-Table 2, Fig. 1b). By the second retrieval date $48-94 \%$ of seeds for all species except Lehmann lovegrass had germinated (Fig. 2). Thus, expected species-specific germination responses were in agreement with hydrotime parameter values of Adams (1997).

Lehmann lovegrass field germination was generally lower than expected based on germination rates and moisture requirements determined in laboratory studies. Roundy and Biedenbender (1996) found $50 \%$ of germinating Lehmann lovegrass to germinate in 2.2 to 3.7 days under summer seedbed temperatures. Lehmann lovegrass total germination and germination rate vary widely within and among seed lots (Hardegree and Emmerich 1991), and germination response varies with temperature, water stress, light, seed priming, seed age, and wet-dry sequences (Knipe and Herbel 1960, Tapia and Schmutz 1971, Frasier 1989, Jordan and Haferkamp 1989, Hardegree and Emmerich 1992a,1992b, Roundy et al. 1992a, 1992b). Lehmann lovegrass germination was low in constant darkness, but increased with exposure to red light and with exposure to fluorescent light and alternating temperature (Tapia and Schmutz 1971, Roundy et al. 1992a). Lehmann lovegrass germination in the field may have been limited by conditions of low light associated with burial of the seed bags, and subsequent high residual germinability was expressed after exposure to light in the laboratory. However, a small percentage of seeds of Lehmann lovegrass germinate in darkness (Roundy et al. 1992a) and some seeds germinated after burial in soil at a depth of $0.6 \mathrm{~cm}$ (Winkel et al. 1991). The highly variable germination responses of Lehmann lovegrass to a variety of environmental conditions (Hardegree and Emmerich 1991), helps explain why some subpopulations germinate under initial rainfall conditions and others delay germination. This hypothesis is supported by the observation that Lehmann lovegrass produced multiple cohorts of emerged seedlings after sowing directly into soil at this field site (Abbott 1999).

\section{Recruitment Study}

Seedling survival at the end of the growing season was significant for all possible 2-way interactions of year, sowing date, 


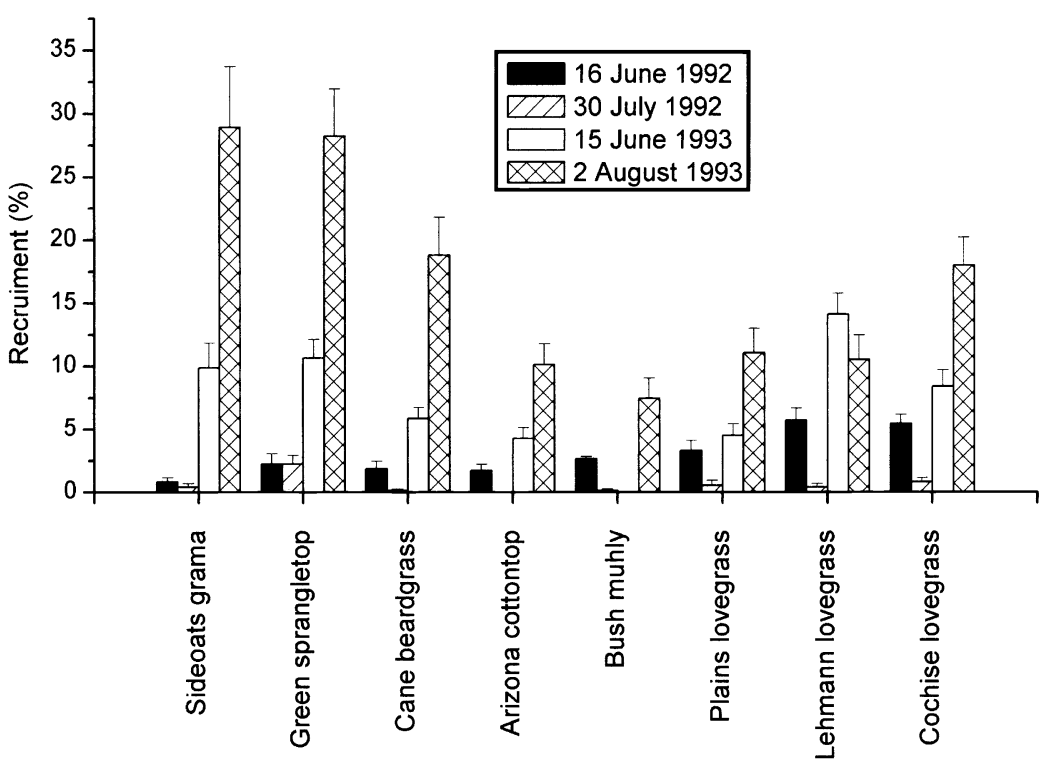

Fig. 3. Mean recruitment as a percentage of number of seeds sown for warm-season grass species seeded on 4 dates on a sandy loam upland site in southeastern Arizona. Error bars represent standard errors of the means.

and species (year $\mathrm{x}$ sowing date $\mathrm{df}=1,4$, for all others $\mathrm{df}=7,56$ ) but was not significant for the 3-way interaction of those factors $(\mathrm{df}=7,56, \mathrm{P}=0.33)$. Of all possible 2-way interactions, the interaction of year and sowing date was strongest $(\mathrm{p}=$ 0.0002 ). In 1992, more seedlings established from the 16 June sowing $(2.6 \%)$ than from the 30 July sowing $(0.6 \%)$; in 1993, the 15 June sowing $(7.2 \%)$ resulted in fewer established seedlings than did the 2 August sowing (16.7\%). In general, more seedlings established for each species in 1993 than in 1992, but the magnitude of the difference among years differed among species (Fig. 3). For example, seedling recruitment was lowest for bush muhly in $1992(0.2 \%)$ and in 1993 (3.7\%). In 1992, Lehmann lovegrass $(3.1 \%)$ and Cochise lovegrass $(3.1 \%)$ had the highest seedling establishment, whereas in 1993 green sprangletop had the highest seedling recruitment $(19.5 \%)$. When considering the interaction of species and sowing date, bush muhly had the lowest seedling recruitment for all species in both the pre-summer $(0.1 \%)$ and mid-summer (3.8\%) sowings. Lehmann lovegrass had the highest seedling recruitment for the pre-summer sowings (9.9\%), and green sprangletop had the highest seedling recruitment for the mid-summer plantings $(15.3 \%)$. In general, the number of established seedlings for the mid-summer sowings was either greater or not different than the pre-summer sowings for all species except Lehmann lovegrass.

Successful recruitment requires envi- ronmental conditions that promote germination and support continued seedling growth. Once seeds have germinated, seedling survival is compromised if the soil drying front surpasses the advancing seminal root depth in the absence of additional rain (Roundy et al. 1997). Seminal roots must supply water to the seedling until adventitious roots develop near the soil surface. That requires 9 days to 3 weeks of available water at the soil surface for these warm-season grasses (Roundy et al. 1993, Abbott 1999). Knowing the time of germination, estimating seminal root growth, and knowing the soil water availability by depth, it should be possible to predict seedling success or failure (Roundy et al. 1997). Seminal root growth varies with species, soil moisture, and ambient conditions (Abbott 1999, Olmsted 1941, Sosebee and Herbel 1969, Simanton and Jordan 1986, Roundy et al. 1993), but could be liberally estimated at $1 \mathrm{~cm}^{\text {day }}{ }^{-1}$.

Using this approach, seminal root depth would have been exceeded by the soil drying front before substantial adventitious root development for seeds sown 30 July 1992 and 15 June 1993. Establishment failure was predicted for these sowing dates, while actual establishment in the sub-plots averaged $0.6 \%$ for the 1992 date and $7.2 \%$ for the 1993 date. An associated study conducted at the same time on nearby plots where these same species were sown in rows resulted in limited seedling establishment of native grasses when sown on similar dates (Biedenbender and Roundy 1996). In contrast, seedling suc- cess would be expected to be higher for the 16 June 1992 and 2 August 1993 sowing dates where the soil drying front would not have exceeded the depth of seminal roots, thereby allowing over 3 weeks of available water for adventitious root development. Actual establishment for these dates averaged $2.6 \%$ for the 16 June 1992 sowing date and $16.7 \%$ for the 2 August 1993 sowing date. Seeds of native grasses sown in rows where Lehmann lovegrass was controlled on this site produced 5.6 seedlings $\mathrm{m}^{-2}$ when sown in mid June 1992 and 12.7 seedlings $\mathrm{m}^{-2}$ when sown early August 1993 (Biedenbender and Roundy 1996).

A review of the chronology of germination and seedling growth in relation to available water patterns for each sowing date helps clarify reasons for success or failure. For the 16 June 1992 sowing date, initial rains resulted in 9.3 days of available water near the surface (L2- Table 2) and high field germination (Fig.1a, Fig. 2). Soil drying proceeded for approximately 10 days between the end of the initial rainy period and beginning of the next rain. The drying front did not exceed the estimated seminal root depth (Fig. 1a) and seedlings would be expected to have survived until the second rainy period. In contrast, seeds that germinated after the 30 July 1992 sowing were exposed to 11 days of available water, 7.2 days of dry soil, 0.8 days of wet soil, and then 4.7 days of dry soil (L4- Table 2). The depth of the drying front exceeded the estimated seminal root depth within 13 days of germination. The next wet period of 8.3 days (Table 2 ) would only benefit seedlings that survived the previous 12 days of dry soil conditions or those seeds that remained ungerminated yet germinable. Residual germination after the first retrieval date of the 30 July 1992 sowing varied from 3.3 to $42.5 \%$ for all species except Lehmann lovegrass $(83.0 \%)$. Therefore, less than half of the planted seeds for all species except Lehmann lovegrass had the potential to germinate during that second, 8-day moist period. Furthermore, the subsequent dry period lasted over 8.9 days, during which time the survival of recently emerged seedlings would have been unlikely.

Moisture conditions following the 15 June 1993 sowing resulted in low initial germination (S5- Table 2, Fig. 2). Relatively high germination of all species except Lehmann lovegrass occurred by the second retrieval date (S6). However, the second retrieval date was followed by a 15-day dry period (Fig. 1b). During this rainless period, the drying front exceeded 
the estimated seminal root depth 12.5 days after germination. In contrast, in the 32 days following the 2 August sowing, only 2 short drying periods occurred, the drying front never exceeded the estimated seminal root depth, and seedling establishment was high. There was sufficient time of available water near the soil surface to support development of adventitious roots for all the sowing dates (17-26 days). The lack of available water to allow seminal roots to support seedlings during intermittent dry periods for the 30 July 1992 and 15 June 1993 sowing dates best explains the failure of those seedings.

\section{Management Implications}

Our investigation of germination response of seeds planted under field conditions clearly revealed species-specific response patterns to dynamic soil moisture conditions. Smith et al. (2000) also found intraspecific responses of Arizona cottontop seedling emergence to soil water. Many native grass species exhibit high and rapid germination, and would be favored by rainfall and long periods of available water subsequent to germinating rains. For these species, the planted seedbank can be depleted after the initial rain event. The risk of seeding failure is high if lengthy dry periods occur after germination. The seedbank of Lehmann lovegrass with more conservative germination would not be depleted by initial rain events. The occurrence of lengthy dry periods following initial rains imposes less risk to reseeding success of this species. This is due to the potential for subsequent rain events to promote germination and growth of remaining germinable seeds. Successful recruitment of Lehmann lovegrass in rows on both pre- and mid-rainy season sowing dates supports this conclusion (Biedenbender and Roundy 1996).

Rainfall and soil moisture patterns widely vary between and within years. Environmental conditions during 1 growing season may favor establishment of 1 or more species, whereas different environmental conditions may favor the establishment of a different suite of species. Thus, years in which summer soil moisture conditions are highly variable would tend to favor Lehmann lovegrass over faster-germinating native species.

The tendency for Lehmann lovegrass to germinate a small proportion of seeds in response to individual rainfall events, yet retain a residual seedbank typifies a bethedging strategy that is favorable in variable environments (Venable 1989), and is 1 reason for the relative success of
Lehmann lovegrass reseedings in regions characterized by low precipitation (Cable 1971, Cox et al. 1982). Long-term summer precipitation records in southeastern Arizona indicate that the probability of rain sequences in which the initial rain event is followed by dry periods lasting 5 days or less is maximized between the third week of July and the first week of August (Frasier and Lopez 1990, Roundy et al. 1996, 1997). Given the rapid germination response and concomitant depletion of seedbank reserves exhibited by native species in this study, chances for successful establishment of native grass species in revegetation projects in southeastern Arizona may be increased by delaying sowing until at least the third week of July.

\section{Literature Cited}

Abbott, L.B. 1999. Effects of sowing date and species choice on the fate of planted warmseason perennial grass seeds: implications for revegetation. Ph.D. Thesis, Univ. of Arizona, Tucson, Ariz.

Adams, C.R. 1997. Germination strategies of native and exotic warm-season perennial grasses in response to variable moisture, light, and temperature. MS Thesis. Brigham Young University, Provo, Utah.

Biedenbender, S.H. and B.A. Roundy. 1996. Establishment of native semidesert grasses into existing stands of Eragrostis lehmanniana in southeastern Arizona. Restoration Ecol. 4:155-162.

Bradford, K.J. 1990. A water relations analysis of seed germination rates. Plant Phys. 94: 840-849.

Breckenfeld, D.J. and D. Robinett. 1997. Soil and range resource inventory of the Santa Rita Experimental Range, Pima County, Arizona. USDA, NRCS and the Univ. of Arizona, Tucson, Ariz.

Cable, D.R. 1971. Lehmann lovegrass on the Santa Rita Experimental Range, 1937-1968. J. Range Manage. 24:17-21.

Collis-George, N. and J.E. Sands. 1959. The control of seed germination by moisture as a physical property. Austr. J. of Agr. Res. 10:628-636.

Colman, E.A. and T.M. Hendrix. 1949. The fiberglass electrical soil-moisture instrument Soil Sci. 67:425-438.

Conover, W.J. and R.L. Iman. 1981. Rank transformations as a bridge between parametric and nonparametric statistics. Amer. Statist. 35:124-129.

Cox, J.R. and G.L. Jordan. 1983. Density and production of seeded range grasses in southeastern Arizona (1970-1982). J. Range Manage. 36:649-652.

Cox, J.R., G.B. Ruyle, and B.A. Roundy. 1990. Lehmann lovegrass in southeastern Arizona: biomass production and disappearance. J. Range Manage. 43:367-372.
Cox, J.R., H.L. Morton, T.N. Johnsen, G.L. Jordan, S.C. Martin, and L.C. Fierro. 1982. Vegetation restoration in the Chihuahuan and Sonoran Deserts of North America. USDA, ARS, Agr. Reviews and Manuals, ARM-W-28.

Frasier, G.W. 1989. Characterization of seed germination and seedling survival during the initial wet-dry periods following sowing. J. Range Manage. 42:299-303.

Frasier, G.W. and F. Lopez. 1990. Optimizing wet-dry precipitation probabilities for improving plant establishment. Watershed Planning and Analysis in Action Symposium Proc.of Irrigation Conf. p. 395-404. American Society of Civil Engineers, July 9-11, 1990. Durango, Colo.

Frasier, G.W., J.R. Cox, and D.A. Woolhiser. 1985. Emergence and survival response of seven grasses for six wet-dry sequences. J. Range Manage. 38:372-377.

Frasier, G.W., J.R. Cox, and D.A. Woolhiser. 1987. Wet-dry cycle effects on warm-season grass seedling establishment. J. Range Manage. 40:2-6.

Frasier, G.W., D.A. Woolhiser, and J.R. Cox. 1984. Emergence and seedling survival of two warm-season grasses as influenced by the timing of precipitation: a greenhouse study. J. Range Manage. 37:7-11.

Green, C.R. and S.C. Martin. 1967. An evaluation of precipitation, vegetation and related factors on the Santa Rita Experimental Range. Institute of Atmospheric Physics Tech. Rep. on Meteorology and Climatology of Arid Regions, Number 17. Univ. of Arizona Press, Tucson, Ariz.

Gummerson, R.J. 1986. The effect of constant temperatures and osmotic potentials on the germination of sugar beet. J. Exp. Bot. 37:729-741.

Hardegree, S.P. and W.E. Emmerich. 1991. Variability in germination rate among seed lots of Lehmann lovegrass. J. Range Manage. 44:323-326.

Hardegree, S.P. and W.E. Emmerich. 1992a. Effect of matric-priming duration and priming water potential on germination of four grasses. J. Exp. Bot. 43:233-238.

Hardegree, S.P., and W.E. Emmerich. 1992b. Seed germination response of four southwestern range grasses to equilibration at subgermination matric-potentials. Agron. J. 84:994-998.

Hegarty, T.W. 1978. The physiology of seed hydration and dehydration, and the relation between water stress and the control of germination: a review. Plant, Cell, and Environ. 1:101-119.

Humphrey, R.R. 1958. The desert grassland. Botanical Review 24:193--253.

Jordan, G.L. 1981. Range seeding and brush management on Arizona rangelands. Univ. of Arizona Agr. Exp. Station Bull. T81121. Tucson, Ariz.

Jordan, G.L. and M.R. Haferkamp. 1989. Temperature responses and calculated heat units for germination of several range grasses and shrubs. J. Range Manage. 42:41-45.

Knipe, D. and C.H. Herbel. 1960. The effects 
of limited moisture on germination and initial growth of six grass species. J. Range Manage. 13:297-302.

Littel, R.C., G.A. Milliken, W.W. Stroup, and R.D. Wolfinger. 1996. SAS ${ }^{\circledR}$ system for mixed models. SAS Institute, Inc., Cary, N.C.

Martin, S.C. 1966. The Santa Rita Experimental Range: a center for research on improvement and management of semidesert rangeland. United States Forest Service Research Paper RM-22. Rocky Mountain Forest and Range Experiment Station. Fort Collins, Colo.

McClaran, M.P. 1995. Desert grasslands and grasses. p 1-30 In: M.P. McClaran, and T.R. Van Devender (eds.) The Desert Grassland. Univ. of Arizona Press, Tucson, Ariz.

Olmsted, C.E. 1941. Growth and development in range grasses. I. Early development of Bouteloua curtipendula in relation to water supply. Bot. Gazette. 102:499-519.

Ries, R.E. and T.J. Svejcar. 1991. The grass seedling: When is it established? J. Range Manage. 44:574-576.

Roundy, B.A. and S.H. Biedenbender. 1995. Revegetation in the desert grassland. p. 265-303. In: M.P. McClaran, and T.R. Van Devender (eds), The desert grassland. Univ. of Arizona Press, Tucson.

Roundy, B.A. and S.H. Biedenbender. 1996. Germination of warm-season grasses under constant and dynamic temperatures. J. Range Manage. 49:425-431.
Roundy, B.A., L.B. Abbott, and $M$ Livingston. 1997. Surface soil water loss after summer rainfall in a semidesert grassland. Arid Soil Res.and Rehabilitation 11:49-62.

Roundy, B.A., R.B. Taylorson, and L.B. Sumrall. 1992a. Germination responses of Lehmann lovegrass to light. J. Range Manage. 45:81-84.

Roundy, B.A., J.A. Young, L.B. Sumrall, and M. Livingston, M. 1992b. Laboratory germination responses of 3 lovegrasses to temperature in relation to seedbed temperatures. J. Range Manage. 45:306-311.

Roundy, B.A., V.K. Winkel, J.R. Cox, A.K. Dobrenz, and H. Tewolde. 1993. Sowing depth and soil water effects on seedling emergence and root morphology of three warm-season grasses. Agron. J. 85:975-982.

Roundy, B.A., L.B. Abbott, C. Jones, S.H. Biedenbender, $M$. Livingston, and V.K.Winkel. 1996. Warm-season grass establishment in relation to summer rainfall patterns. p. 484-485. In: N.E. West (ed.) Proc.Fifth International Rangeland Congress, Volume 1. Soc. for Range Manage., Denver, Colo.

Simanton, J.R. and G.L. Jordan. 1986. Early root and shoot elongation of selected warmseason perennial grasses. J. Range Manage. 39:63-67.
Smith, R.E. and H.A. Schreiber. 1973. Point processes of seasonal thunderstorm rainfall: 1. Distribution of events. Water Resourc. Res. 9:871-884.

Smith, S.E., E. Riley, J.L. Tiss, and D.M. Fendenheim. 2000. Geographical variation in predictive seedling emergence in a perennial desert grass. J. Ecol. 88:139-149.

Sosebee, R.E., and C.H. Herbel. 1969. Effects of high temperature on emergence and initial growth of range plants. Agron. J. 61:621-624.

SRER, 1999. Box Canyon precipitation data, 1968-1998. Santa Rita Experimental Station precipitation records. Univ. of Arizona, Tucson, Ariz.

Tapia, C.R. and E.M. Schmutz. 1971 Germination responses of three desert grasses to moisture stress and light. J. Range Manage. 24:292-295.

Venable, D.L. 1989. Modeling the evolutionary ecology of seedbanks. p 67-90. In: M.A. Leck, V.T. Parker, and R.L. Simpson (eds.) Ecology of soil seed banks. Academic Press, San Diego, Calif.

Winkel, V.K., B.A. Roundy, and D.K. Blough. 1991. Effects of seedbed preparation and cattle trampling on burial of seeds. $\mathrm{J}$. Range Manage. 44:171-175.

Wilson, A.M. and D.D. Briske. 1979. Seminal and adventitious root growth of blue grama seedlings Agron. J. 68: 479-484. 